DOI: 10.12731/2658-4034-2020-3-24-29

\title{
НАЦИОНАЛЬНО-КУЛЬТУРНАЯ СПЕЦИФИКА КОММУНИКАТИВНОГО ПОВЕДЕНИЯ ФРАНЦУЗОВ
}

\section{Муриева М.В.}

Северо-Осетинский государственный университет имени Коста Левановича Хетагурова, г. Владикавказ, Республика Северная Осетия-Алания, Российская Федерация

В статье речь идет о сохранении в отечественной системе образования, наряду с английским языком, преподавания одного из востребованных европейских языков, в частности, франиузского. Чтобы студенты могли эффективно общаться с носителями языка, необходимо, помимо сформированных языковых и речевых умений и навыков, знание начионально-культурных черт франиузского коммуникативного поведения.

Ключевые слова: языки; культура; английский язык; французский язык; общение; коммуникативное поведение.

\section{ETHNIC AND CULTURAL IDENTITY OF FRENCH COMMUNICATION BEHAVIOR}

\section{Murieva M.V.}

North Ossetian State University named after Kosta Levanovitch Khetagurov Vladikavkaz city, Republic of North Ossetia-Alania, Russian Federation

The article reveals the idea of maintaining the teaching of French language within the national education system as one of the popular European languages along with English language teaching. In order students are able to communicate effectively with native speakers it is critical to learn 
about ethnic and cultural features of French communication behavior besides attained language skills.

Keywords: languages; culture; English language; French language; communication; communication behavior.

В современном поликультурном и полилингвальном пространстве функционирует большое количество диалектов и языков. Любой язык - это культурное богатство и достояние народа, говорящего на нем. Более 1,5 миллиарда человек пользуются сегодня английским языком как инструментом общения и коммуникации, включая глобальную сеть интернет и другие средства международной коммуникации. Фактически речь идет о формировании новой культуры мира с английским языком во главе.

По мнению Д.Кристала, именно английский язык (и его американский вариант) является родным для большинства жителей стран мира и более чем в 70-ти государствах он является официальным языком. Не только лаконичность и красота звучания английского языка оказались для многих очень притягательными, но и ряд других известных всем факторов, способствующих его выдвижению как глобального средства общения между представителями разных культур, говорящих на разных языках. Можно согласиться с тем, что человечеству давно нужен был единый универсальный язык, на котором бы говорило большинство людей земного шара, как одно из средств избежать непонимания и конфликтов.

Однако такое положение рассматривается как опасная тенденция с явным перекосом в сторону одного языка и возведение его в ранг элитного, что автоматически влечет ненадобность и бесполезность других языков и культур, а, возможно, и их скорейшее вытеснение и исчезновение из употребления. Особенно в большой опасности находятся языки «малых» этносов и народов, которым Юнеско уже предрекает исчезновение в ближайшие 40-50 лет, хотя и предпринимает много усилий, чтобы оттянуть этот процесс. Английский же язык продолжает свое триумфальное шествие по планете. Все большее число людей выражают желание изучать английский язык, 
вступать в межкультурную коммуникацию с носителями языка и англофонами, использовать его практически в личных или профессиональных целях. Сегодня вряд ли можно найти компетентного специалиста, не владеющего английским языком.

Мы считаем, что традиционно преподаваемые в российских учебных учреждениях всех уровней (дошкольный, школьный, среднепрофессиональный, вузовский, постдипломный) европейские языки и сегодня не утратили своей актуальности. Несмотря на то, что за английским языком прочно закрепился статус глобального, международного делового языка, европейские языки - немецкий, французский, итальянский, испанский, преподаваемые не так давно в качестве первых иностранных языков (далее ИЯ) в отечественном образовании, постепенно переходят в статус второстепенных.

Проблема заключается в том, что на современном этапе для дальнейшего гармоничного развития и успешного самоопределения учащихся старших классов, проявляющих способности и интерес к лингвистике, необходимо владение не одним, а двумя, а то и тремя языками как в качестве первого ИЯ, так и в качестве вторых ИЯ в школах с углубленным изучением ИЯ или же факультативного курса на профильно-ориентированном уровне.

Студенты, изучающие английский язык в качестве первого ИЯ, владеют умениями и навыками работы с текстом, лексическим и грамматическим материалом, переводом, пересказом. Они также обладают опытом изучения русского и родного языков, что способствует формированию умений находить аналогии в изучаемых языках, сравнивать и сопоставлять их, анализировать и, на основе наблюдений, делать выводы и обобщения. Принадлежа к разным языковым группам (славянской, германской, романской) и имея общую индоевропейскую составляющую, все эти три языка характеризуются как различиями, так и схожими явлениями. Однако существенно облегчается процесс усвоения языков при наличии схожих языковых явлений. Поэтому, освоение второго/третьего ИЯ происходит быстрее, легче и эффективнее. А.С. Ягубова, М.В. Муриева считают, что «сравнивая культурные особенности народов - носителей 
этих языков, учащиеся пополняют свои знания, раздвигают свои представления о мире, становятся поликультурными языковыми личностями, для которых характерны такие черты, как открытость ко всему новому, толерантность и дружелюбное отношение по отношению к другим народам и культурам. Однако иноязычное обучение в нашей стране не должно ограничиваться рамками одного английского языка» [2, с. 1841].

Сегодня ученые признают, что экспансия английского языка на многие языки мира никогда не была такой активной, как в последние годы. И если английский язык - глобальный, то для чего еще нужны другие языки? Нужно ли их изучать?

Речь идет об изучении французского языка, который входит в десятку наиболее часто используемых языков в современном мире. Один из рабочих языков ООН, ЮНЕСКО, Совета Европы и многих МО (МОК, Всемирный Совет мира, Всемирная конфедерация труда, Международный суд, Всемирная организация здравоохранения и др.), французский язык - красивейший и богатейший язык, на котором сегодня говорят более 300 млн.людей на планете. Это не только язык великих философов, поэтов, художников, мыслителей, который вобрал в себя передовые европейские идеи во всех областях человеческой деятельности, но и носитель значимых культурных и эстетических ценностей. Давние языковые, дипломатические и коммерческие контакты между Россией и Францией способствовали проникновению культуры Франции в Россию на протяжении многих лет и оказали на нее самое благоприятное влияние.

Чтобы успешно общаться с носителями изучаемого языка, сегодня недостаточно овладеть фонетическим, лексико-грамматическим строем языка и всеми видами речевой деятельности. Нужны знания иного порядка, касающиеся специфики коммуникативного поведения представителей изучаемой культуры, т.н. общекультурные и ситуативные нормы общения, формирующиеся на протяжении определенного периода времени. Доминирующей чертой коммуникативного поведения французов авторами (Р.А.Ермакова, И.А. Стернин, С.Г. Стернина, В.С. Сухарев и др.) признана вежли- 
вость (la politesse), которая в ряде сфер (например, обслуживания или деловой и др.) выступает обязательным атрибутом имиджа служащего любой области деятельности данного лингвосоциума. Отличительными чертами коммуникативного поведения повседневной жизни французов выделены улыбчивость, в отличие от бытовой неулыбчивости русских (Ю.Е. Прохоров), приветливость, высокий уровень бытовой вежливости, демонстрация жизнерадостности и сохранение самоконтроля в процессе общения.

Замечено, что в беседах с друзьями, знакомыми, соседями французы стараются не навязываться и не задавать лишних вопросов, предпочитая конкретику («Bonjour!», «ça va?», «Quoi de neuf?», «Au revoir!»). Французы, чаще, чем русские, могут долго извиняться или просить прощение за неудобства, возникшие по их вине. Легкий переход в беседе на «ты» (tutoyer) и непринужденный стиль общения также характерен для современного француза. В общении со знакомыми и близкими им людьми обязательно соблюдаются этикетные нормы, принятые в этом обществе.

Интересно, что французское коммуникативное поведение приоритетным выдвигает дискуссионный характер общения, быстрый переход к диалогу, избыточность крайних оценочных элементов; нежелание «загружать» малознакомых людей своими проблемами и просьбами. Француз всегда старается показать себя с выгодной стороны, т.е. произвести хорошее впечатление («блеснуть» в разговоре, удачно пошутить, продемонстрировать свое остроумие и т.д.). Однако на работе, службе представители этой национальности не очень общительны, предпочитая, в основном, молча и качественно выполнять свою работу. В общественных местах французы не нарушают личного пространства партнера по общению, строго соблюдая общепринятую культурную дистанцию и не допуская физических прикосновений к нему.

Итак, можно утверждать, что в подавляющем большинстве случаев коммуникативное поведение французов соответствует вышеназванным характеристикам и носит ярко выраженную национальную окраску, что находит свое отражение как в соблюдении ими обще- 
культурных норм поведения, так и ситуативных. При обучении эффективному общению студентов на французском языке все вышеназванные параметры обязательно учитываются. В курсе «Основы межкультурной коммуникации», читаемом на языковом факультете, подробно освещены вопросы национально-культурной специфики американцев, англичан, французов, немцев, арабов, японцев и др.

Вместе со студентами мы резюмируем, что в каждой культуре исторически сложились собственные правила общения и деловой коммуникации, которые у разных народов проявляются по-разному.

\section{Список литературы}

1. Белая Е.Н. Теория и практика межкультурной коммуникации. М.: «ФОРУМ», 2014. $208 \mathrm{c}$.

2. Yagubova A.S., Murieva M.V. Linguocultural approach as modern experience in learning foreign languages. // The European Proceedings of Social \& Behavioural Sciences EpSBS Conference: SCTCGM 2018 - Social and Cultural Transformations in the Context of Modern Globalism. Conference Chair(s): Bataev Dena Karim-Sultanovich - Doctor of Engineering Sciences, professor, director of the Complex Scientific Research Institute n. a. H.I. Ibragimov of the Russian Academy of Sciences. 2019. Серия книг: European Proceedings of Social and Behavioural Sciences. Vol. 58. P. 1841.

\section{References}

1. Belaya E.N. Teoriya i praktika mezhkul'turnoy kommunikatsii. M.: «FORUM», 2014. $208 \mathrm{~s}$.

2. Yagubova A.S., Murieva M.V. Linguocultural approach as modern experience in learning foreign languages // The European Proceedings of Social \& Behavioural Sciences EpSBS Conference: SCTCGM 2018 - Social and Cultural Transformations in the Context of Modern Globalism. Conference Chair(s): Bataev Dena Karim-Sultanovich Doctor of Engineering Sciences, professor, director of the Complex Scientific Research Institute n. a. H.I. Ibragimov of the Russian Academy of Sciences. 2019. Seriya knig: European Proceedings of Social and Behavioural Sciences. Vol. 58. P. 1841. 